\title{
The Orientation of Academic Project in Engineering
}

\author{
William Patrick Geraldo ${ }^{\text {* }}$, Waldemar Bonventi Junior ${ }^{1}$, José Roberto Garcia ${ }^{1}$, Ana Laura Schliemann ${ }^{2}$ \\ 1. UNISO- University of Sorocaba, Brazil \\ 2. PUC - Pontifical Catholic University of São Paulo, Brazil
}

How to cite this paper: Geraldo, W. P. Junior, W. B., Garcia, J. R., \& Schliemann A. L. (2018). The Orientation of Academic Project in Engineering. The Educational Review, USA, 2(5), 272-280.

http://dx.doi.org/10.26855/er.2018.05.001

*Corresponding author: William Patrick Geraldo, UNISO- University of Sorocaba, Brazil.

\begin{abstract}
Engineering has been getting closer and closer to people's lives in a very short time period, although present in the technology of televisions, cars, clothes, among other equipment and services. Currently, in Brazil, the engineer's work brought people closer to their problems and, therefore, the importance of training professionals with the ability to identify, evaluate and solve them. The main objective of this article is to present the teaching methodology adopted in the Supervised Project Course for the creation of Engineering Degree Project and to demonstrate some work done close to people and their "interfaces" with the health area. At the University of Sorocaba (UNISO) the Computer Engineering course adopted the active methodology of learning based on the Problem-Based Learning (PBL). This caused the students to get in touch with the community, their problems and needs. Then, these situations were discussed during the lessons in order to solve the problems identified. It should be noted that the choice of subjects was free and most focused on problems related to health, disability and sustainability. The construction of knowledge was carried out through the discussion of the theory in practice in an applied, descriptive and qualitative research on this experience. The students attended the needs of the topics of the work developed, such as: 1) Pité (therapeutic robot that helps in the treatment of childhood diseases); 2) prototypes to help the mobility of people with tetraplegia using wheelchairs. The proposal of the work with the PBL and project-based learning was important for the development of skills of autonomy and social responsibility that helped in the formation of participatory and responsible citizens in their community.
\end{abstract}

\section{Keywords}

PBL, Engineering, Learning, Human Problems

\section{Introduction}

Following the new proposals related to engineering learning, the University of Sorocaba (UNISO), is a community university located in Sorocaba, state of São Paulo - Brazil, where it has three campuses: University City Campus Professor Aldo Vannucchi, inaugurated in 1999; Trujillo Campus, where it was deployed to the Faculty of Philosophy, Sciences and Letters in 1954 and the Seminar Campus in 1994. The UNISO was founded in 1951, but began its activities only in 1954 when it began the undergraduate courses in: Pedagogy and NeoLatinos lyrics, only with 27 students. UNISO currently has more than 60 undergraduate degrees and offers degrees in Lato Sensu and Stricto Sensu, as well as extension courses (UNISO, 2017).

UNISO offers 12 specialization degrees in engineering: Environment, Bioprocesses, Biotechnology, Electrical, Civil, Control and Automation, Mechanics, Materials, Chemistry, Food Production and Computer Engineering. The engineers conclude their engineering graduation in five years of study (UNISO, 2017). The form of teaching is at UNISO, which is 
traditional and always seeks to motivate their teachers to seek new ways of learning.

As part of our commitment to training and in order to allow students to assess their general performance, interests and research skills to continue "learning to learn", the engineering degrees have the course "Supervised Project". This course is mandatory for students who are in the last two years of the engineering degree. The process aims to build the "final project" (Degree Assignment), which challenges the students to get in contact with the communities and identify their problems and solve them.

The Supervised Project Course is a mandatory requirement in the Computer Engineering course that contributes to the training of new professionals who work in the areas of industrial computing, industrial communication networks, information systems, application to engineering, computer systems and embedded computing. Part of its mission is to: to specify, develop, implement, adapt, manufacture, install and maintain computer systems (UNISO, 2017).

The main objective of this article is to present the teaching methodology adopted in the Supervised Project Course for the creation of the Degree Assignment (DA) of engineering graduation and to demonstrate some work done for the people and their "interfaces" with the Health area.

When developing the DA, students are challenged to apply the knowledge acquired in the course and also seek new external knowledge - it is a class that becomes a small learning laboratory.

We understand that only a discipline that is at the end of the course will not reach all the objectives proposed in this article for the training of students, but it can be a first step in the direction of a change that is necessary in the proposed traditional teaching process.

\section{Problem-Based Learning (PBL) and Engineering}

The search for dynamism in teaching and better learning outcomes have always been the subject of studies. The evolution of learning becomes relevant aspects of knowledge and construction skills to live in a society. It provides differentiated learning configuration that allows the approximation and integration between teacher and student, which favors the collective construction of knowledge (Sharma et al, 2015).

According to Schliemann (2016), active methodologies depend on autonomy.

"The active methodology of learning can be defined as the pedagogical practice based on the principle of autonomy, assumption of contemporary education that students are capable of self-management or self-governing their own training processes. A methodology that assumes the student as the protagonist of a learning scenario focused on the reality and in the context of their professional field. The socialization of innovative experiences can motivate teachers to do a job, reducing the resistance of some professionals to innovate for fear of doing an "amateur" job that does not meet the expectations of students in the external scenario." (Schliemann et al 2016, p.54).

It is also important to mention that when the option is to learn by Active Learning Methodologies, a series of activities techniques are proposed, among them, Problem Based Learning (or "PBL").

The literature associates the PBL with a curriculum change that began at McMaster University in Canada and the University of Maastricht in the Netherlands in the late 1960s. The teachers and coordinators of these universities focused on efforts to overcome some problems related to traditional teaching, especially those related to the content of learning by medical students and their subsequent use in their professional practice (Conrado and Nunes-Neto and El-Hani, 2014).

According to Freitas (2012, p.406), the PBL has its principles:

- Education centered on the student and strongly oriented in their own learning processes - it is understood that the ideal conditions for learning are created;

- Learning is the responsibility of the student - he must understand the problem and develop it, which drastically re- 
duces his passive role in the classroom;

- Consideration in previous experience - they can be spoiled, but you should understand that the students understand the topic to avoid erroneous interpretations;

- Active, interactive and collaborative learning - develops critical thinking of students and awakens their involvement with attentive and respectful listening, collaboration with the team, capacity for analysis, synthesis and judgment by verifying the relevance of their application to the problem ;

- Contextualization of teaching - study of theory and practice applied to the reality of the professions;

- Learning is inductive - solutions deduced by students through applied learning;

- The main role of the teacher as an instructor or tutor - he is more active in activities as a facilitator or tutor;

- The problem or situation-problem always precedes the theory - work on the understanding of the real problems to define the learning objectives and then look for the underlying knowledge and explain scientifically the adopted solution. The practice of engineering is very close to these presented principles.

The evolution of humanity has been directly related to engineering. It is known that the main landmarks of history, such as wars or major catastrophes, serve to lead great achievements and guarantee the life of humanity. Not if it objectifies disasters, but it is observed that these are moments of great cultural and social pressure that becomes engineering (Freitas, 2014).

Engineer involves the idea of putting the experience of a specialist with scientific knowledge in favour of man. The great challenge is to investigate, develop, adapt and, sometimes, find solutions for problems that humanity suffers. We can see, among the examples to follow, that engineering in a historical context through the combination of knowledge, skills and human skills to build the Pyramid of Giza in Egypt, ingenious this that precedes the invention of the steam engine (Bazzo and Pereira, 2006).

Although engineering professionals have become indispensable in the mid-50s, the creation of objects and appliances that we have today and the approximation of people's daily lives, historically we see that the evolution of products of Engineering and technology had mystical characteristics that always seemed "ready" and little is known about the people who developed the technology. Engineering professionals were always in laboratories and, often away from people, what they understood was that there was a distance between these professionals and customers.

Today reality has changed. With the evolution and popularization of technology, the engineers are in television programs, in representations of companies, in front of the audience of consumers with the object to have a close communication with the human beings and not only with the technological problems. Next, the role of the engineer changes from "product creator" to "helpers" in solving problems.

With this change of coexistence, it was also necessary a change in the learning of engineering. The engineer's work together with the problem of humanity has forced teachers to think about the course, to think about the teaching and training of students for this condition. Through these reflections came the need to develop learning simulations lived in the everyday.

Engineers must be identifiers, formulators and problem solvers. In their professional activity, they have information that, properly collected, classified and worked on, can be transformed into practical and useful results. In engineering it is possible to identify, formulate and solve problems that result in the development of a new product, system or process or its improvement (Bazzo and Pereira, 2006).

In an engineering project, it is considered:

- The learning process is directed, but guided by the needs of the project;

- The engineers are responsible for the development of the project; 
- The previous learnings are important to reach solutions;

- The intense interaction and collaboration of the project team, clients and suppliers;

- Learn to apply;

- Analysis of problems before project design.

It is concluded that such considerations bring "Project Based Learning" and "PBL" closer to engineering projects.

\section{Methodology}

The discipline "Supervised Project" is based on the construction of knowledge through practice that led students to perform and applies, descriptive and qualitative survey on the experience of project-based learning.

According to Hernández and Ventura (1998), project-based teaching brings the opportunity to work on global and relational knowledge.

Suertegaray (2003) says that there are topics that are directly linked to interdisciplinary, which consists of a collective practice, originating from organizations by groups and aims to search for the understanding and explanation of a problem formulated by all scientific researchers.

At all times, the student is responsible for their project and the teacher acts as a guide to the research, directing the work in order to meet the projected objectives. The teacher acts with suggestions that, added to the data collected in the research, provides inductive learning.

In all classes, topics such as:

- The progress of the project towards the goal;

- What are the difficulties faced and the possibilities to avoid them?

- The following steps and the corresponding deliveries for the classes that will follow.

These activities are done with a problem that was brought to the class, it generate responses by the idealization of machines and equipments built by the students with the supervision of a professor.

The students developed their Degree Projects respecting the following rules:

- Look for conditions in the community where the use of engineering can facilitate or transform the lives of people;

- To investigate and understand the problem that exists in other scientific works until the condition of the community being studied is fully met;

- In the classroom, contextualize the situation and understand the problem through discussions with the professor of the course;

- Create hypotheses to study possible solutions using previous training;

- Build new hypotheses considering possibilities through unknown studies;

- Create a research project to define the full scope of the project with all the technique and theory considered necessary;

- Present the project to the opinion of other colleagues in the classroom. A very rich moment where everyone has the opportunity to collaborate in the search of better solution;

- Investigate the issues necessary for the development of the project. At that time it is important to work the technical conditions;

- Test the hypothesis by building a functional and presentable prototype that can be scaled for the application to the real solution of the problem. In many cases students need to return for research, usually for reasons of technical feasibility, and then work on the necessary adjustments;

- $\quad$ Present the prototype for various types of tests that can be applied in its construction and its scale of construction; 
- Create technical documentation about the construction of the prototype;

- Promote the discussion about the whole process of expulsion of the project in a determined time in documentary form and also recognize the learning in the whole process;

- Consolidate the entire project in document format within the scientific and academic methodologies that we call "Degree Assignment";

- Present the written assignment and the prototype for the evaluators of the Degree Course that are composed of university professors and guests.

The adaptation of PBL and project-based learning, formed the basis for the development of student projects.

\section{Development of Degree Assignment}

The works respected the conditions of Computer Engineering training that combined the use of hardware and software aimed at an engineering application, through the construction of a functional and presentable prototype in front of an everyday problem.

The discipline "Supervised Project" proposed to twenty students who attended the classes, the challenge of learning together with the community, first, looking for the problems that people face every day and that engineering can help to solve them. Divided into three modules, the course is given in a year and a half with a total workload of 200 hours, for a total of 240 classes of 50 minutes duration, for a year and a half.

In the first module called "Supervised Project I", students understand what an engineering project is, to move to the community looking for nearby issues of human problems and then bring them as subject for the Degree Assignment. In addition, to create a research project that details each step of the execution, using methods of construction of the scientific work proposed by the University. The evaluation criterion is through the presentation of the structured and scientifically based research project that demonstrates the feasibility of the engineering project.

Table 1. The descriptions of four projects.

\begin{tabular}{|c|c|c|c|}
\hline Title & Objective & Relation to the community & Grade \\
\hline $\begin{array}{l}\text { Assistance Technology } \\
\text { for Tetraplegic People }\end{array}$ & $\begin{array}{l}\text { Help in the locomotion of patients } \\
\text { with tetraplegia }\end{array}$ & $\begin{array}{l}\text { With the movement of the head, which is the only } \\
\text { possible condition of the body in tetraplegia, the } \\
\text { patient gets the independence and autonomy to } \\
\text { move and control the wheelchair motors }\end{array}$ & 10 \\
\hline $\begin{array}{l}\text { Use of Technology to the } \\
\text { Height of Personal } \\
\text { Security }\end{array}$ & $\begin{array}{l}\text { Develop a smartphone applicative } \\
\text { that automatically notifies the user's } \\
\text { family, by sending their location }\end{array}$ & $\begin{array}{c}\text { With so many crimes happening, the user informs } \\
\text { his family that everything is fine or sends an } \\
\text { emergency message to ask for help and his/her } \\
\text { location }\end{array}$ & 9 \\
\hline $\begin{array}{l}\text { Braille Touch-Virtual } \\
\text { Keyboard }\end{array}$ & $\begin{array}{c}\text { Assistance to learn Braille for the } \\
\text { visually impaired }\end{array}$ & $\begin{array}{l}\text { Learning Braille is not an easy task and requires a } \\
\text { lot of training and concentration. The application, is } \\
\text { through a screen of printed film with Braille cells, } \\
\text { guides the student to identify which letter } \\
\text { corresponds to the Braille cell that is felt at the } \\
\text { fingertips through the sound. }\end{array}$ & 10 \\
\hline $\begin{array}{l}\text { Robot Pite: Therapeutic } \\
\text { Robot of Assistance to } \\
\text { Children }\end{array}$ & $\begin{array}{l}\text { Help children in understanding the } \\
\text { hospitalization process. }\end{array}$ & $\begin{array}{l}\text { Providing the child, in a playful way through a } \\
\text { robot and an animated story on a Tablet that, at the } \\
\text { same time, brings a distraction, provides } \\
\text { understanding and acceptance in the hospitalization } \\
\text { process. }\end{array}$ & 10 \\
\hline
\end{tabular}


The second module, "Supervised Project II", provides students with the experience of conducting the research project built in the previous six months, with the documentation of its application, the necessary changes for the feasibility of the engineering project. At that time the student has the opportunity to test the full meaning of the research with practice. The evaluation in this stage requires students to present a prototype of work that manage the problem studied.

In the last module, "Supervised Project III", the delivery of the functional and presentable prototype is evaluated. The prototype being "presentable" means that it can be presented to the target audience and does not present malfunctions in the environment to which it will be applied. At the same time, the student must present a scientific article. The final evaluation is carried out through the evaluators who are two university professors and the work counsellor who analyses the written work, the prototype and the presentation of the project, with the aim of validating the knowledge of the student in their training area, the use of new knowledge and the proposed engineering solution. In addition to the evaluation of student performance, a set of parameters is established for the correct introduction of the student in the scientific community, the search for intellectual and personal satisfaction and preparation for the labour market.

The thematic options developed are free and spontaneous and address issues related to the health area. During the period, four projects were completed and are described in the Table 1.

\subsection{Results of the Use of the Methodology through the Objectives Achieved by the Degree Assignments}

Next, there are two abstracts of works that have received the final grade of ten (which is the highest grade), to demonstrate that the methodology applied makes it possible for the development of the Degree Projects to reach their objectives with the community and, more than that, the learning and the construction of knowledge. All the rules listed in the methodology presented in this paper were applied to the students.

\subsection{Identify the Headings}

Headings, or heads, are organizational devices that guide the reader through your paper. There are two types: component heads and text heads.

Component heads identify the different components of your paper and are not topically subordinate to each other. Examples include Acknowledgements and References and, for these, the correct style to use is "Heading 5". Use "figure caption" for your Figure captions, and "table head" for your table title. Run-in heads, such as "Abstract", will require you to apply a style (in this case, non-italic) in addition to the style provided by the drop down menu to differentiate the head from the text.

Text heads organize the topics on a relational, hierarchical basis. For example, the paper title is the primary text head because all subsequent material relates and elaborates on this one topic. If there are two or more sub-topics, the next level head should be used and, conversely, if there are not at least two sub-topics, then no subheads should be introduced. Styles named "Heading 1", "Heading 2", "Heading 3", and "Heading 4" are prescribed.

\subsection{Robot Pite: Therapeutic Robot}

Research developed by students Adriano Bastos and Fernando José Viana under the direction of Professor William Patrick Geraldo brings the proposal in the summary below and with Figure 1.

"The research appeared in an interdisciplinary way with students and professors of Computer Engineering and Psychology to promote the humanization of the illness in childhood. Hospitalization is considered a stressful experience for the child, breaking the ties with the family and the environment in which they live, and maintaining normality through play is fundamental to address this time of life. When a child becomes ill, their reality and daily life change resulting in feel- 
ings of fear and helplessness that are crucial in this period of life and that are worse at the time of hospitalization. The game demystifies the hospital environment as hostile and can gain a nice view, as well as allow the emotional expression and development of the kid, also makes the child has a connection with professionals who care about it and increases their interaction with parents who are often invited to participate. In response to the questions asked in this research, we have developed a robot controlled through an application via Bluetooth, synchronized with the video, which informs the experiences of a seven-year-old girl with the hospitalization process (the Pitedoll)" (Bastos \& Viana, 2016).
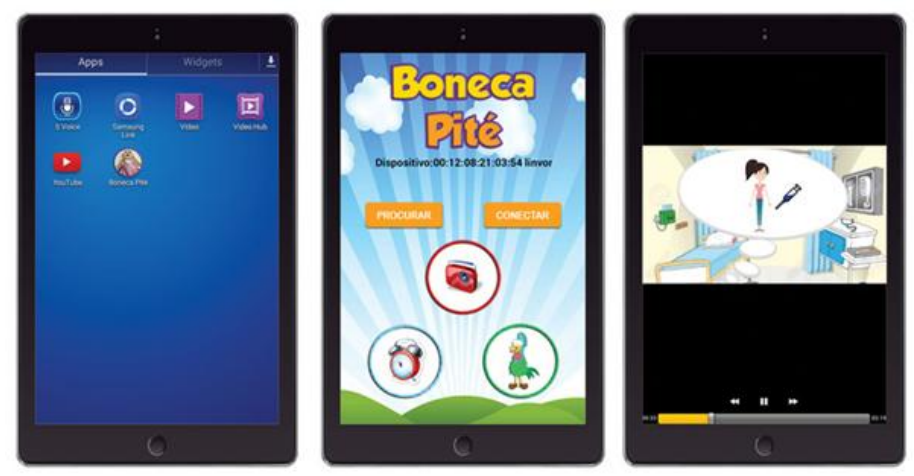

Figure 1. Application used by the robot to tell the story.

The story is presented through the animation with a duration of five minutes for "Tablet" and "Smartphone" counted by the robot Pite as shown in Figure 2 (Bastos and Viana, 2016).
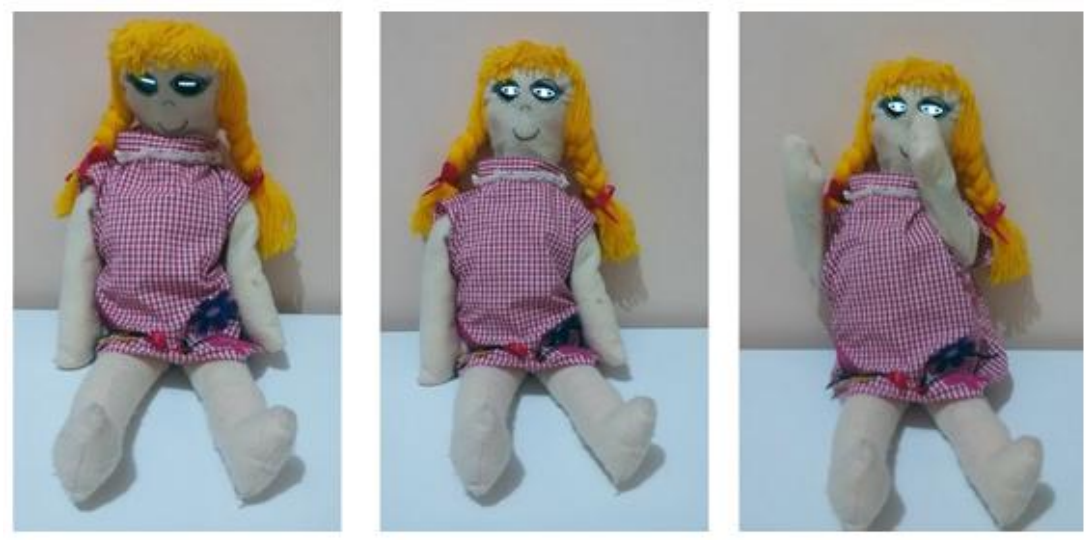

Figure 2. Robot Pité - the therapeutic fabric doll.

"The help of tablet technology and the robot in the hospital environment brings impact and curiosity in children, which facilitates contact. The presentation of the story with the technology facilitates the interaction and understanding of the child in front of the hospital procedures exemplified in the video and the process of the illness and / or death of children and adolescents" (Bastos and Viana, 2016).

\subsection{Prototype to Aid Mobility in Wheelchairs for People with Tetraplegia}

The research developed by the students Tobias Afonso dos Santos Bastos and Kaisa Soares de Almeida under the direc- 
tion of Professor William Patrick Geraldo brings the proposal in the summary below and is illustrated in Figure 3.

"This study aimed to develop an Android applicative with the function of helping people suffering from tetraplegia. Through the facial recognition of the OpenCV library, the applicative has the ability to send commands via Bluetooth to a prototype of a wheelchair built with the Arduino microcontroller. The origin of this project is based on the perception of the need that people with physical disabilities, especially tetraplegia, have less expensive and accessible devices to offer them more independence. This knowledge was applied and served so that this project could have a satisfactory final result" (Bastos and Almeida, 2016).

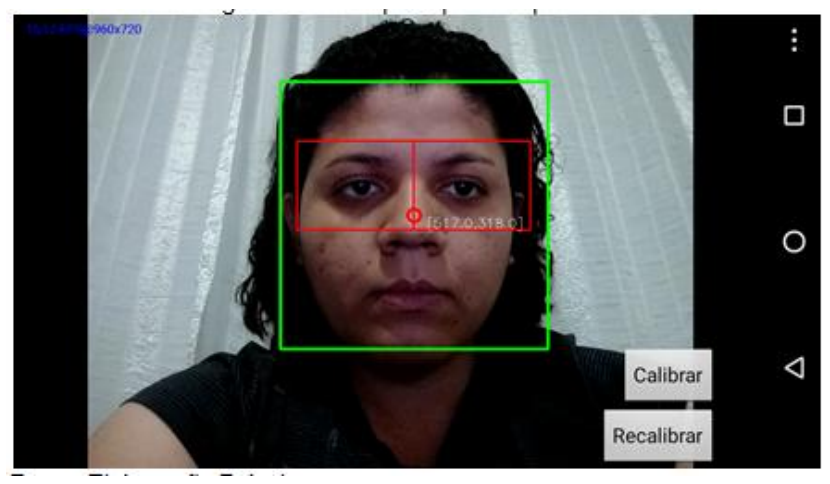

Figure 3. Identification and classification of images to move the face motors.

The students also reported the daily experience of the engineers around adverse issues faced during the execution of the project:

"Due to the limitations encountered in the course of the same, it was not possible to develop a prototype closer to what a wheelchair is, but the final product can give a very narrow view of how it should be applied in the future for facilities that help to reproduce a wheelchair better. Some important conclusions were obtained about the use of artificial vision and currently available libraries, which allows the development of tools that help improve the lives of many people with difficulties. It was shown that it is not necessary to access very advanced tools for very useful devices and that the Arduino microcontroller, which has a simple programming, can provide very high efficiency and can be used for many projects even in health" (Bastos y Almeida, 2016).

\section{Discussion: Identification of the Problems and Impacts of the Solutions Produced}

The impact of the works presented here demonstrates the benefits to the subjects studied, and reproduced in a community, generates significant achievements in people's lives, such as: "Happiness of children when knowing Pite and knowing that she went through the moments that the children were experiencing"; "The possibility of locomotion autonomously even with the limitations of a wheelchair". As those solutions were applied, they have provided new opportunities to improve, and new challenges, which led to the search for new solutions, which leads us to say that this way of working in engineering, makes the engineering feedback constantly.

For students, this experience brought significant learning, so that it is in touch with the challenges of the engineering profession. It is evident the construction of knowledge, the application of the same and exposure to constant and different levels of learning. 


\section{Final Conclusions}

In resumption of the objective of this presentation, it was possible to expose the discipline and some of the developed works. On the basis of the principles of PBL, it was possible to demonstrate the uniqueness through the completion of the Degree Assignment done in the course called "Supervised Project" with the students of Computer Engineering of the University of Sorocaba (UNISO).

The PBL proposes a time of reflection of the daily academic practice, from the theoretical frame of the significant learning in front of the work dynamics through the Learning Based on Problems. The technique encourages reflection on "Learning to learn" in the face of the need to reorganize knowledge towards the solutions adopted.

For the professor, what stands out the most is the opportunity to learn in front of the knowledge constructed by the students and to make sure that in that moment the real learning occurred.

As for the students, the experience of building solutions for the daily life of people and providing them with a better quality of life, contributed to the formation of true engineers and great citizens.

This implementation experience is discussed with the commission so that other disciplines can act on the same point of view on the training of Computer Engineering students.

It is expected that the results presented here have shown the importance of this discipline for the formation of participatory citizens and renowned responsible engineers, closer to people and everyday life.

\section{References}

Bastos, A. de S., \& Viana, F. J. (2016). Boneca pité robô terapêutico na assistência à criança. Trabalho de conclusão de curso. UNISO. Sorocaba, SP, Brasil.

Bastos, A. T. dos S., \& Almeida, K. S. (2016). Dispositivo para auxílio aos portadores da tetraplegia. Trabalho de conclusão de curso. UNISO. Sorocaba, SP, Brasil.

Bazzo, W. A., \& Pereira, L. T. do V. (2006). Introdução à engenharia. Conceitos, ferramentas e comportamentos. Ed. da UFSC. Florianópolis, SC, Brasil.

Chouman, A. M. (2016). Projeto de captação e reaproveitamento de água em equipamentos de climatização. Trabalho de conclusão de curso. UNISO. Sorocaba, SP, Brasil.

Conrado, D. M., Nunes-Neto, N. F., \& El-Hani, C.1 N. (2014). Problem Based Learning (PBL) in science teaching as a strategy for the education of socially and environmentally responsible citizens. Journal Brasileira de Pesquisa em Educação em Ciências. 14, 2 , Brazil.

Freitas, C. A. (2014). Introdução à engenharia. First edn. Pearson. São Paulo, Brasil.

Freitas, R. A. M. da M. (2012). Ensino por problemas: uma abordagem para o desenvolvimento do aluno. Educ. Pesqui, 38(2), 403-418.

Hernández, F., \& Ventura, M. (1998). A organização do currículo por projetos de trabalho. Tradução Jussara Haubert Rodrigues. 5. ed. Porto Alegre: Artes Médicas, Brasil.

Hernandez, R. S., Fernandez, C. C., \& Baptista, M. D. P. L. (2013). Metodologia de pesquisa. 5. ed. Porto Alegre: AMGH, 624p, Brasil.

MILIONI, B. (2012). Análise metodizada de problemas e busca de soluções: para consultores, gestores, técnicos e estudantes. Coletânea de métodos. Rio de Janeiro: QualityMark, 2e.

Pinheiro, J. M. S. (2010). Da iniciação científica ao TCC: uma abordagem para os cursos de tecnologia. Ciência moderna, Brasil.

Schliemann, A. L., Antonio, J. L. et al. (2016). Metodologias Ativas na UNISO: Formando cidadãos participativos. EDUNISO. São Paulo, Brasil.

Souza, C. A., Morales, O. E. T. et al. (2015). Coleção Mídias Contemporâneas. Convergências Midiáticas, Educação e Cidadania: aproximações jovens. Ponta Grossa: UEPG, Vol. II,PG: Foca Foto-PROEX/UEPG, Brasil.

Suertegaray, D. M. A. (2003). Geografia e interdisciplinaridade. Espaço geográfico: interface natureza e sociedade. Florianópolis: Geosul, 18(35), 43-53, Brasil.

UNISO, Universidade de Sorocaba. (2017). Portal Institucional. [online] www.uniso.br. Sorocaba, SP, Brasil. Aceso en 01 abril de 2017. 